\author{
Y.Y. Yermekov, D.B. Toimbayeva, S.G. Kamanova, L.A. Murat, \\ M. Muratkhan, S.A. Saduakhasova, G.S. Aidarkhanova, G.Kh. Ospankulova* \\ Saken Seifullin Kazakh Agrotechnical University, Nur-Sultan, Kazakhstan \\ *Corresponding author: bulashevag@mail.ru
}

\title{
Investigation of the effect of acetylation on the physicochemical properties of grain starches
}

\begin{abstract}
Use of acetylated starches in the production of composite biodegradable materials is a promising direction, since acetylation increases the water-resistant properties of starches. This article presents the results of studies on the effect of acetylation of wheat A and corn starches with glacial acetic acid on the physicochemical properties of polysaccharides and the study of the potential of using modified starches to obtain a composite mixture of biodegradable films. Comparative studies of the physicochemical properties of polysaccharides and their modifications have illustrated that acetylation leads to a decrease in the proportion of amylose in starch, and also reduces the swelling of starch. It has been revealed that the degree of substitution in starches increases only at the initial stages of the acetylation reaction, which is possibly associated with the rheology of starches common to corn and wheat A during swelling and gelatinization. With a decrease in the amount of acetylating agent, a more uniform course of the reaction is observed, the granules destroyed after absorbing the maximum amount of moisture still have access points for replacement with acetyl groups, the reaction proceeds more slowly, but deeper. Solubility depends more on the reaction time. The optimal technological parameters for obtaining acetylated starches have been determined. For wheat starch A, the following are optimal: the concentration of glacial acetic acid is 1: 6, the reaction time is 40 minutes; for corn starch: concentration of glacial acetic acid 1: 5, reaction time 60 minutes. Samples of acetylated starches obtained under such conditions are convenient for preparing a composite mixture of biodegradable materials.
\end{abstract}

Keywords: wheat A starch, corn starch, amylose, swelling, solubility, acetylation, rheology, starch modification.

\section{Introduction}

The packaging materials, mainly polyethylene, which is durable and degradable for more than hundred years, creates a serious problem for the environment all over the world. This problem is also highly relevant in Kazakhstan. In addition, according to the EU Directive (EC 94/62 "SDA-Green Mark"), the responsibility of the packaging manufacturer for the life cycle of the packaging put into circulation on the market is determined. As a member of the World Trade Organisation (WTO) being fully compliant with its requirements, the problem of packaging recycling is also arised in our country.

The most attractive alternatives to petroleum-based or synthetic-based plastic packaging are polymers derived from a variety of renewable natural resources such as starch, cellulose, chitosan, plant and animal proteins. An affordable, inexpensive, renewable, and degradable natural polymer is starch. However, poor water resistance and low strength are limiting factors for the use of materials made from starch. These problems are solved by chemical modification of starch, which allows obtaining optimal functional properties for packaging materials.

Despite a plenty of studies being done on biodegradable starch-based materials, there are still challenges and opportunities to improve productivity and reduce costs, in particular to improve the recognized weakness of starch-based materials: moisture sensitivity.

Starch is a polysaccharide that can be synthesized by plants and is found mainly in fruits, root tubers, legumes and cereals, usually its content varies from 25 to $90 \%$. Unlike other polysaccharide polymers, which are harvested or recovered by destroying plants, starch can be harvested in most cases without destroying them [1]. Starch is stored by plants in a partially crystalline, water-insoluble granule form, the size and composition of which depends on the plant source [2,3]. Due to its complete biodegradability [4], low-cost and renewability [3-5] starch is considered as a promising candidate for the development of environmentally friendly materials. The hydrophilic nature of starch is a major limitation that severely limits the development of starch-based products, so chemical modification is a way to solve the problem when making waterproof materials [6]. Acetylation is one of the best studied and implemented chemical 
modifications on the industrial level and is based on the esterification of starch with acetyl groups $\left(-\mathrm{COCH}_{3}\right)$ to form starch acetates [7]. The introduction of acetyl groups helps to reduce interactions between the outer chains of amylopectin and amylose chains, imparting new properties to the polymer. Authors found that the introduction of acetyl groups during acetylation reduces the bond strength between starch molecules and thereby increases the swelling and solubility of starch granules, reduces starch coagulation, and provides improved freeze-thaw stability. As with all chemical reactions, acetylation depends on factors such as reagent concentration, reaction time and $\mathrm{pH}$, which finally determine the number of acetyl groups [8].

Aim of this work is to study the potential of wheat A and corn starches acetylated with glacial acetic acid to obtain a composite mixture of biodegradable materials.

\section{Experimental}

Materials. Industrial samples of starches were used in the work: corn starch was purchased from Zharkent Starch Plant LLP, Zharkent, wheat A starch was provided by BioOperations LLP, Taiynsha. All used chemicals were of analytical grade.

The total protein content was determined on a semi-automatic complex (Keltron 4005, Sibagropribor, Russia), which includes a digestor, a scruber, and a distillation unit, titration was carried out manually, according to the Association of Official Agricultural Chemists (AOAC) method 2011.11 "Protein (crude) in animal feed, plant tissues, grain and oilseeds", the method of block ashing using a copper sulfate catalyst with steam distillation into boric acid.

Lipid content was determined on an automated Buchi device (Extraction Unit E-812). To carry out the analysis with an error of no more than $0.1 \mathrm{~g}$, a sample of starch $25-50 \mathrm{~g}$ was transferred into a disposable cellulose cartridge and weighed. Then the cartridge was placed in an extraction sleeve and mounted on the device. Chloroform in a volume of $100 \mathrm{ml}$ was used as a solvent. The analysis was conducted in three stages: 1. Extraction takes place at $100 \%$ heating and lasts 60 minutes, includes 6 cycles; 2. Drying lasts 60 minutes at $100 \%$ heating; 3. Rinsing lasts for 25 minutes at $70 \%$ heat. After the completion of the extraction, the cartridge was weighed with an error of not more than $0.001 \mathrm{~g}$ and the percentage of lipids was calculated.

Content of amylose and amylopectin was identified according to the method described by Juliano [9].

Determination of phosphate content. The content of phosphates in native and oxidized starches was determined according to GOST 7698-93 "Starch. Acceptance rules and methods of analysis".

Preparation of acetylated corn and wheat A starch

Acetylated starch was prepared according to the study by Kumoro, Amalia, Budiyati, Retnowati, and Ratnawati with modifications. $100 \mathrm{~g}$ of starch was dispersed in $500 \mathrm{ml}$ of distilled water to obtain a starch suspension with a concentration of $20 \%$. A magnetic stirrer was applied to get a uniform suspension. Then the $\mathrm{pH}$ from the suspension was raised to a value of 8 by adding a solution of $1 \mathrm{M} \mathrm{NaOH}$, after which the temperature was raised to $50{ }^{\circ} \mathrm{C}$. Then, to the reaction suspension was added a predetermined amount of glacial acetic acid $(1: 5,1: 6,1: 7)$, which led to a sharp decrease in $\mathrm{pH}$. The $\mathrm{pH}$ was returned to its original state by the addition of $1 \mathrm{M} \mathrm{NaOH}$. The reaction proceeded from 40 to $60 \mathrm{~min}$, after which the reaction was stopped by bringing the $\mathrm{pH}$ to 5.5 by adding $1 \mathrm{M} \mathrm{HCl}$, the acetylated starch after precipitation was washed three times from acid with distilled water, and then dried at room temperature, after which the degree of substitution, the ability to swell and solubility was increased [10].

Determination of Acetyl Group Content (\%) and Degree of Substitution (DS)

To determine the degree of substitution (DS), the percentage of acetyl groups (\% Ac) ((1), (2)) was determined by titration according to the method of Würzburg (1986). Acetylated starch $(1.0 \mathrm{~g})$ was placed in a $250 \mathrm{ml}$ flask and $50 \mathrm{ml}$ of $75 \%$ diluted ethanol in distilled water was added. The samples were heated in a water bath at $50{ }^{\circ} \mathrm{C}$ for $30 \mathrm{~min}$, and after cooling, $40 \mathrm{ml}$ of $0.5 \mathrm{~N}$ hydrochloric acid was added. $\mathrm{NaOH}$, then the mixture was kept under stirring at $200 \mathrm{rpm}$ for 72 hours. The excess alkali was titrated with $0.5 \mathrm{~N}$. $\mathrm{HCl}$, using phenolphthalein as an indicator. The neutralized solution was stirred for $2 \mathrm{~h}$ and the excess alkali was titrated. A control sample was also used with the original unmodified starch [11].

$$
\begin{gathered}
\text { Acetyl groups } \%=\frac{[(\text { Control Sample }(\mathrm{ml})-\operatorname{Sample}(\mathrm{ml})) \times \text { Molarity } \mathrm{HCl} \times 0.043 \times 100}{\operatorname{Sample} w e i g h t(\mathrm{~g})}, \\
D S=\frac{163 \times \text { Acetyl groups }(\%)}{[4300-(42 \times \operatorname{Acetyl} \operatorname{groups}(\%))]} .
\end{gathered}
$$


Determination of solubility and swelling

Water solubility (WS) and swelling power (SP) of native and acetylated starches were analyzed based on the method of Li and Yeh (2001). A $1.0 \mathrm{~g}$ starch sample (W0) was accurately weighed and quantitatively transferred into a clear dried tube and reweighed as $\mathrm{W} 1$. Then the starch was dispersed in $50 \mathrm{ml}$ of distilled water. The resulting suspension was heated at $60^{\circ} \mathrm{C}$ for $30 \mathrm{~min}$ with constant stirring. The mixture was cooled to $30^{\circ} \mathrm{C}$ and centrifuged at $100 \mathrm{xg}$ for $15 \mathrm{~min}$.

Aliquots $(5 \mathrm{ml})$ of the supernatant were dried to constant weight at $110^{\circ} \mathrm{C}$ and designated as $\mathrm{WC}$. The residue, obtained after drying the supernatant, represented the amount of starch dissolved in water. Solubility was calculated as g per $100 \mathrm{~g}$ starch based on dry weight according to formula 3 .

$$
W S=\frac{W C}{W O} \times \frac{50}{5} \times 100 .
$$

The supernatant was separated, the swollen starch was weighed as a precipitate. The residue, obtained in the aforementioned experiment (after centrifugation) with the water stored therein, was quantitatively transferred to a clean drying test. The previously used tube was weighed (W2). To calculate the swelling capacity, the weight of the residue was divided by the original weight after subtracting the solubility [12].

Rheology of Acetylated Starch

The rheology of starches was determined using a Rapid Visco Analyzer (RVA 4500, Perten Instruments, Sweden). Distilled water $(25 \mathrm{ml}$ ) was added to starch weighed portions weighing $3 \mathrm{~g}$ (in dry form), then the samples were first equilibrated at $50^{\circ} \mathrm{C}$ for $1 \mathrm{~min}$, then heated to $95{ }^{\circ} \mathrm{C}$ at a rate of $12{ }^{\circ} \mathrm{C} / \mathrm{min}$, held for $2.5 \mathrm{~min}$, then cooled to $50^{\circ} \mathrm{C}$ at $12{ }^{\circ} \mathrm{C} / \mathrm{min}$, held for $2 \mathrm{~min}$.

Statistical Analysis

The results of experimental studies are represented by the average values determined from three parallel measurements. Mathematical processing of measurements was performed using standard computer programs MS Office Excel 2010, IBM SPSS Statistics.

\section{Results}

Currently, most of the starch acetylation is carried out using acetic anhydride and vinyl acetate, which are expensive and hazardous to human health. In this work, glacial acetic acid was used as a modifying agent.

Acetylation of wheat and corn starch was conducted by the suspension method using distilled water as a dispersing agent and sodium hydroxide as a catalyst at a temperature of $53{ }^{\circ} \mathrm{C}$. The influence of the mass fraction of glacial acetic acid on the solubility in water and the swelling power of acetylated starch are presented in Table 1.

T a b l e 1

Influence of different ratios of glacial acetic acid and wheat A starch on water solubility (WS), swelling power (SP) and degree replacement of acetylated starch at pH 8

\begin{tabular}{|c|c|c|c|c|c|c|c|c|c|}
\hline \multirow[b]{2}{*}{$\begin{array}{c}\text { Time } \\
\text { (minutes) }\end{array}$} & \multicolumn{3}{|c|}{$1: 5$} & \multicolumn{3}{|c|}{$1: 6$} & \multicolumn{3}{|c|}{$1: 7$} \\
\hline & $\begin{array}{c}\mathrm{WS} \\
\mathrm{g} / 100 \mathrm{~g}\end{array}$ & $\begin{array}{l}\mathrm{SP} \\
\%\end{array}$ & DS & $\begin{array}{c}\mathrm{WS} \\
\mathrm{g} / 100 \mathrm{~g}\end{array}$ & $\begin{array}{l}\mathrm{SP} \\
\%\end{array}$ & DS & $\begin{array}{c}\mathrm{WS} \\
\mathrm{g} / 100 \mathrm{~g}\end{array}$ & $\begin{array}{l}\mathrm{SP} \\
\% \\
\end{array}$ & DS \\
\hline 0 & $\begin{array}{c}4.05 \pm \\
0.178\end{array}$ & $\begin{array}{c}5.39 \pm \\
0.001\end{array}$ & 0 & $\begin{array}{c}4.05 \pm \\
0.178\end{array}$ & $\begin{array}{c}5.39 \pm \\
0.001\end{array}$ & 0 & $\begin{array}{c}4.05 \pm \\
0.178\end{array}$ & $\begin{array}{c}5.39 \pm \\
0.001\end{array}$ & 0 \\
\hline 40 & $\begin{array}{c}5.49 \pm \\
0.204 \\
\end{array}$ & $\begin{array}{l}5.28 \pm \\
0.0007\end{array}$ & $\begin{array}{c}2.08 \pm \\
0.017 \\
\end{array}$ & $\begin{array}{c}4.06 \\
\pm 0.011 \\
\end{array}$ & $\begin{array}{l}4.89 \pm \\
0.0003 \\
\end{array}$ & $\begin{array}{l}1.2 \pm \\
0.026 \\
\end{array}$ & $\begin{array}{c}3.45 \pm \\
0.495 \\
\end{array}$ & $\begin{array}{l}5.45 \pm \\
0.0006 \\
\end{array}$ & $\begin{array}{l}1.93 \pm \\
0.0422 \\
\end{array}$ \\
\hline 50 & $\begin{array}{c}3.30 \pm \\
0.127\end{array}$ & $\begin{array}{c}5.55 \pm \\
0.004\end{array}$ & $\begin{array}{c}2.02 \pm \\
0.077\end{array}$ & $\begin{array}{c}4.06 \pm \\
0.138\end{array}$ & $\begin{array}{l}4.96 \pm \\
0.0008\end{array}$ & $\begin{array}{l}1.97 \pm \\
0.031\end{array}$ & $\begin{array}{c}3.56 \pm \\
0.575\end{array}$ & $\begin{array}{l}5.46 \pm \\
0.0009\end{array}$ & $\begin{array}{l}2.13 \pm \\
0.0178\end{array}$ \\
\hline 60 & $\begin{array}{c}3.28 \pm \\
0.128\end{array}$ & $\begin{array}{c}5.88 \pm \\
0.001\end{array}$ & $\begin{array}{l}1.95 \pm \\
0.004\end{array}$ & $\begin{array}{l}7.73 \pm \\
0.149 \\
\end{array}$ & $\begin{array}{l}6.18 \pm \\
0.0006\end{array}$ & $\begin{array}{c}2.05 \pm \\
0.044\end{array}$ & $\begin{array}{c}2.86 \pm \\
0.691 \\
\end{array}$ & $\begin{array}{l}5.67 \pm \\
0.0007 \\
\end{array}$ & $\begin{array}{c}2.15 \pm \\
0.009 \\
\end{array}$ \\
\hline
\end{tabular}

The values of the degree of substitution in starches increased only at the initial stages of acetylation reaction, which is possibly associated with the rheology of starches common to corn and wheat A during swelling and gelatinization. The granules absorbed water and retained it while swelling and increasing the viscosity, since the acetylation process was carried out in an environment with a temperature of $53{ }^{\circ} \mathrm{C}$. This effect was pronounced in samples, where the reaction medium had a greater amount of glacial 
acetic acid, absorbing the medium inside the granules undergoing a violent reaction, but with an increase in the reaction time, the supramolecular structures holding the structures of the granules were destroyed and the acetylating agent could no longer carry out the acetylation reaction, since the reaction surface was already acetylated due to the aggressive initial reaction. With a decrease in the amount of acetylating agent, a more uniform course of the reaction was observed, the granules destroyed after absorbing the maximum amount of moisture still had access points for replacement with acetyl groups, the reaction proceeded more slowly, but deeper. This phenomenon was also discovered by a group of scientists led by Kumoro et al. [10].

As can be seen from Table 1, native wheat A starch has a low swelling power and solubility in water, which are $5.39(\%)$ and $4.05(\mathrm{~g} / 100 \mathrm{~g})$, respectively. The amylose content in wheat A and corn starch is 23.51 and $24.32 \%$, respectively.

Table 2 indicates that native corn starch, as well as native wheat A starch, has a low swelling power and solubility in water, which are $5.28(\%)$ and $4.4(\mathrm{~g} / 100 \mathrm{~g})$, respectively.

Table 2

Influence of different ratios of glacial acetic acid and corn starch on water solubility (WS), swelling power (SP) and the degree of substitution of acetylated starch at $\mathrm{pH} 8$

\begin{tabular}{|c|c|c|c|c|c|c|c|c|c|}
\hline \multirow[b]{2}{*}{$\begin{array}{c}\text { Time } \\
\text { (minutes) }\end{array}$} & \multicolumn{3}{|c|}{$1: 5$} & \multicolumn{3}{|c|}{$1: 6$} & \multicolumn{3}{|c|}{$1: 7$} \\
\hline & $\begin{array}{c}W S \\
g / 100 \mathrm{~g}\end{array}$ & $\begin{array}{l}\text { SP } \\
\%\end{array}$ & DS & $\begin{array}{c}\text { WS } \\
\mathrm{g} / 100 \mathrm{~g}\end{array}$ & $\begin{array}{l}\text { SP } \\
\%\end{array}$ & DS & $\begin{array}{c}\text { WS } \\
\mathrm{g} / 100 \mathrm{~g}\end{array}$ & $\begin{array}{l}\text { SP } \\
\%\end{array}$ & DS \\
\hline 0 & $\begin{array}{c}4.40 \pm \\
0.251\end{array}$ & $\begin{array}{c}5.28 \pm \\
0.001 \\
\end{array}$ & 0 & $\begin{array}{c}4.40 \pm \\
0.251\end{array}$ & $\begin{array}{l}5.28 \pm \\
0.001\end{array}$ & 0 & $\begin{array}{l}4.40 \pm \\
0.251\end{array}$ & $\begin{array}{c}5.28 \pm \\
0.001\end{array}$ & 0 \\
\hline 40 & $\begin{array}{l}5.66 \pm \\
0.025\end{array}$ & $\begin{array}{l}7.44 \pm \\
0.001\end{array}$ & $\begin{array}{c}0.69 \pm \\
0.009\end{array}$ & $\begin{array}{c}4.92 \pm \\
0.185\end{array}$ & $\begin{array}{l}7.42 \pm \\
0.002\end{array}$ & $0.77 \pm 0$ & $\begin{array}{c}4.35 \pm \\
0.421\end{array}$ & $\begin{array}{c}7.99 \pm \\
0.001\end{array}$ & $\begin{array}{c}0.8 \pm \\
1.1102\end{array}$ \\
\hline 50 & $\begin{array}{c}4.91 \pm \\
0.688\end{array}$ & $\begin{array}{c}5.49 \pm \\
0.002\end{array}$ & $\begin{array}{c}0.91 \pm \\
0.008\end{array}$ & $\begin{array}{l}5.34 \pm \\
0.574\end{array}$ & $\begin{array}{c}7,54 \pm \\
0.002\end{array}$ & $\begin{array}{c}0.79 \pm \\
0.004\end{array}$ & $\begin{array}{c}2.01 \pm \\
0.124\end{array}$ & $\begin{array}{c}6.64 \pm \\
0.004\end{array}$ & $\begin{array}{c}0.84 \pm \\
0.009\end{array}$ \\
\hline 60 & $\begin{array}{c}8.09 \pm \\
0.109 \\
\end{array}$ & $\begin{array}{c}5.93 \\
\pm 0.0008 \\
\end{array}$ & $\begin{array}{c}0.88 \\
\pm 0.018\end{array}$ & $\begin{array}{c}4.41 \pm \\
0.176 \\
\end{array}$ & $\begin{array}{l}8.14 \pm \\
0.0008\end{array}$ & $\begin{array}{c}0.86 \pm \\
0.008\end{array}$ & $\begin{array}{l}1.99 \pm \\
0.728 \\
\end{array}$ & $\begin{array}{c}5.47 \pm \\
0.003\end{array}$ & $\begin{array}{c}0.86 \pm \\
0.013\end{array}$ \\
\hline
\end{tabular}

The high content of amylose in starch granules leads to the fact that amylose molecules in crystalline form become more compact and intertwined with amylopectin. These structures form a surface; the starch granules become almost solid and prevent the diffusion of water molecules into the starch granules [13].

These patterns are also observed in corn starch, but the degree of substitution in corn starch is less than that in wheat A, perhaps this is due to the increased content of amylose in native corn starch, since amylose is destroyed during acetylation and the destroyed molecular structure of amylose is not further exposed to acetylation, which reduces the overall degree of substitution.

Tables 1, 2 also show that the use of more glacial acetic acid for acetylation does not always increase the solubility of starch in water. Solubility depends more on the reaction time. A similar result was also obtained by Singh et al. on the acetylation of corn and potato starches and Raina et al., who studied the acetylation of rice starch. From the data in Tables 1 and 2, it follows that increasing the reaction time does not always improve the solubility of starch in water in accordance with an increase in the degree of substitution. The high content of amylose in corn starch slows down the rate of the acetylation reaction, as well as an increase in the degree of acetylation. At a low degree of substitution, starch granules of starch are predominantly crystalline or retrograde, which are insoluble in water at ambient temperatures. The slow rate of the acetylation reaction with increasing amylose content may be due to crystals or complexes of amylose [7-14].

According to the data of Tables 1 and 2, DS in starches obtained by acetylation with acetic acid at different concentrations and at different times can be considered high since their limit ranges from 0.69 to 2.15. In this connection, the increase in the swelling of the granules after acetylation was not proportional to the introduction of acetyl groups. Josiane Bartz et al. also illustrate in their studies that acetylation increased the swelling of granules in all modified starches; however, the increase in pellet swelling after acetylation was not proportional to the introduction of acetyl groups, which were more significant in starches with low DS (0.047 and 0.098) and less significant in starch with higher DS (0.125) [15].

Since research is conducted in order to obtain raw materials for the production of biodegradable films, the following samples of acetylated starches were selected for further research: wheat A obtained under conditions: concentration 1:6, reaction time 40 minutes; corn: concentration of glacial acetic acid 1:5, reaction time 60 minutes. This choice is based on the authors' statements that the degree of substitution above 3 leads 
to the fact that films obtained on the basis of acetylated starches with this degree of substitution do not undergo degradation in vivo, and the degree of substitution above 1.9 leads to a two fold increase in the decomposition time. Films compared with samples with a degree of substitution of $1.2[1,16]$.

Comparative studies of the physicochemical properties of native wheat A, corn starch and their modifications (Table 3) demonstrated that the amount of amylose in corn and wheat A starch is approximately at the same level, $24.3 \%$ and $23.5 \%$, respectively.

T a b l e 3

Physical and chemical properties of starch

\begin{tabular}{|l|c|c|c|c|}
\hline \multicolumn{1}{|c|}{ Indicator } & Native wheat A starch & $\begin{array}{c}\text { Acetylated wheat } \\
\text { starch A }\end{array}$ & Native maize starch & $\begin{array}{c}\text { Acetylated maize } \\
\text { starch }\end{array}$ \\
\hline Moisture, \% & $9.42 \pm 0.0823^{\mathrm{b}}$ & $8.6700 \pm 0.1356^{\mathrm{c}}$ & $10.006 \pm 0.0541^{\mathrm{d}}$ & $9.2200 \pm 0.0096^{\mathrm{a}}$ \\
\hline Ash, \% & $0.2463 \pm 0.0162^{\mathrm{a}}$ & $0.2351 \pm 0.0228^{\mathrm{s}}$ & $0.2061 \pm 0.0223^{\mathrm{b}}$ & $0.1753 \pm 0.0128^{\mathrm{b}}$ \\
\hline Phosphate content, \% & $0.0375 \pm 0.0006^{\mathrm{a}}$ & $0.0165 \pm 0.0021^{\mathrm{b}}$ & $0.0416 \pm 0.0014^{\mathrm{s}}$ & $0.0359 \pm 0.0004^{\mathrm{a}}$ \\
\hline Protein content, \% & $1.7066 \pm 0.0644^{\mathrm{b}}$ & $1.2103 \pm 0.0488^{\mathrm{b}}$ & $1.4300 \pm 0.0133^{\mathrm{c}}$ & $1.0006 \pm 0.0511^{\mathrm{a}}$ \\
\hline Amylose content, \% & $23.5100 \pm 0.3399^{\mathrm{a}}$ & $22.5266 \pm 0.4444^{\mathrm{a}}$ & $24.3233 \pm 0.6147^{\mathrm{a}}$ & $23.2126 \pm 0.2135^{\mathrm{a}}$ \\
\hline Content, \% & $0.3347 \pm 0.0168^{\mathrm{a}}$ & $0.2101 \pm 0.0102^{\mathrm{c}}$ & $0.5769 \pm 0.0127^{\mathrm{b}}$ & $0.3659 \pm 0.0230^{\mathrm{bc}}$ \\
\hline
\end{tabular}

Note. $\mathrm{p}<0.05$; Mean value $\pm \mathrm{SD}$ from three repetitions.

The content of phospholipids in starch granules of cereal starches is proportionally related to the content of amylose, since phospholipids, as a rule, form complexes with amylose and long branches of amylopectin and affect the solubility of starch [13]. Physicochemical properties of native starches will have a significant effect on the properties of derivatives, which must be taken into account when modifying starch.

Table 3 designates that the amount of phosphates and lipids correlates with the amount of amylose. The highest amount of amylose $(24.32 \%)$, as well as phosphates $(0.0416 \%)$ and lipids $(0.5769 \%)$, is observed in native corn starch. Wheat A-starch contains amylose $(23.51 \%)$, lipids $(0.3347 \%)$, phosphates $(0.0375 \%)$, and proteins $(1.7 \%)$ and ash content $(0.2463 \%)$.

Whereas in acetylated starches all these indicators, albeit to an insignificant extent, but decrease. This is due to the use of glacial acetic acid and the constant maintenance of the $\mathrm{pH}$ of the suspension at an alkaline level during the acetylation process. A high alkaline environment washes out lipids. Since lipids and phosphates are interconnected and form a phospholipid complex, lipid loss leads to a decrease in phosphate content.

Thus, studies have shown that acetylation of starch leads to a decrease in the proportion of amylose, as well as the swelling of starch. At the same time, with an increase in the mass fraction of amylose, the solubility of acetylated starches decreases and vice versa.

From the data presented in Table 4, it follows that the highest viscosity index achieved during gelatinization has corn starch, but after acetylation, this indicator decreases, perhaps, this is due to the fact that acetylation of starch leads to the destruction of the supramolecular structure of starch because of substitution by acetyl groups.

Table 4

Rheological properties of native and acetylated wheat $A$ and corn starches

\begin{tabular}{|l|c|c|c|c|c|c|c|}
\hline \multicolumn{1}{|c|}{ Sample } & Peak 1 & Trough 1 & Breakdown & Final Visc & Setback & Peak Time & $\begin{array}{c}\text { Pasting } \\
\text { Temp }\end{array}$ \\
\hline Wheat A starch & $3059 \pm 12.52$ & $2363 \pm 25.66$ & $696 \pm 12.66$ & $3589 \pm 45.66$ & $1226 \pm 28.33$ & $6.40 \pm 0.01$ & $81.50 \pm 0.00$ \\
\hline $\begin{array}{l}\text { Acetylated wheat } \\
\text { A starch }\end{array}$ & $2046 \pm 22.23$ & $1703 \pm 17.46$ & $343 \pm 15.69$ & $2270 \pm 52.33$ & $567 \pm 29.33$ & $6.80 \pm 0.03$ & $88.05 \pm 0.05$ \\
\hline Native cornstrach & $3753 \pm 37.66$ & $1743 \pm 19.33$ & $2010 \pm 45.23$ & $3510 \pm 66.66$ & $1767 \pm 25.66$ & $4.53 \pm 0.02$ & $76.70 \pm 0.00$ \\
\hline $\begin{array}{l}\text { Acetylated corn } \\
\text { starch }\end{array}$ & $3036 \pm 38.33$ & $1298 \pm 26.33$ & $1738 \pm 42.66$ & $2967 \pm 48.33$ & $1669 \pm 15.95$ & $4.47 \pm 0.02$ & $75.15 \pm 0.00$ \\
\hline
\end{tabular}

Note. $\mathrm{p}<0.05$; Mean value $\pm \mathrm{SD}$ from three repetitions.

After all the starch granules are completely destroyed, amylose and amylopectin are completely released from the crystal structure and are in free movement in the Breakdown suspension, the lowest viscosity 
is observed in acetylated samples, that is 343.00 and 1738.00 for wheat and corn starches, respectively, which is possibly due to the higher degree of substitution in wheat A starch, which, in comparison with native starch, lost two times in viscosity, while acetylated corn starch with a lower relative degree of substitution lost $15 \%$ compared to native starch.

The value of the final viscosity achieved after the end of gelatinization followed by cooling. Wheat A starch has the highest final viscosity, which is 3589.00 versus corn 3510.00 for native starch (Fig. 1, 2). However, with acetylation, this indicator changes in the opposite direction and is 2270.00 for wheat versus 2967.00 for corn starch.

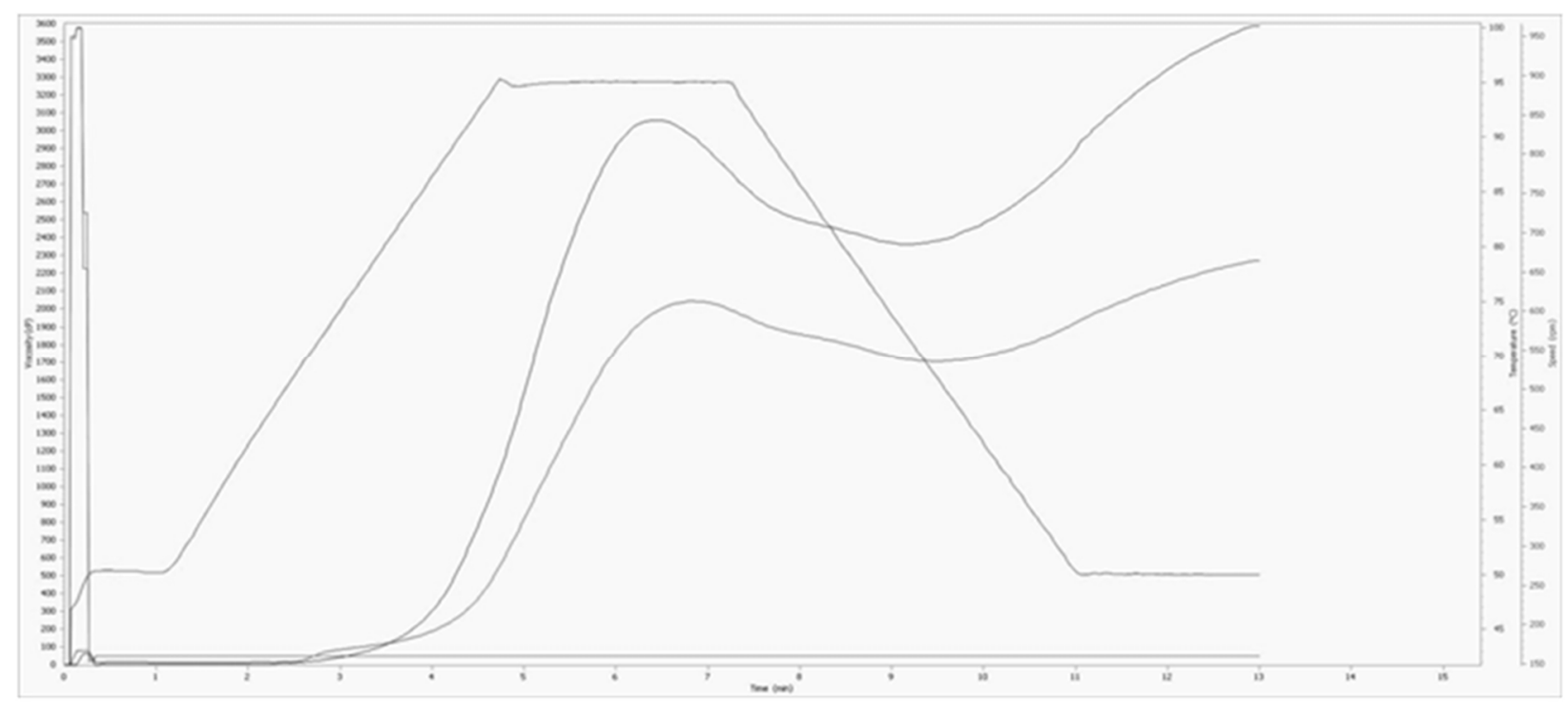

Figure 1. Viscograms of native and acetylated wheat A starch

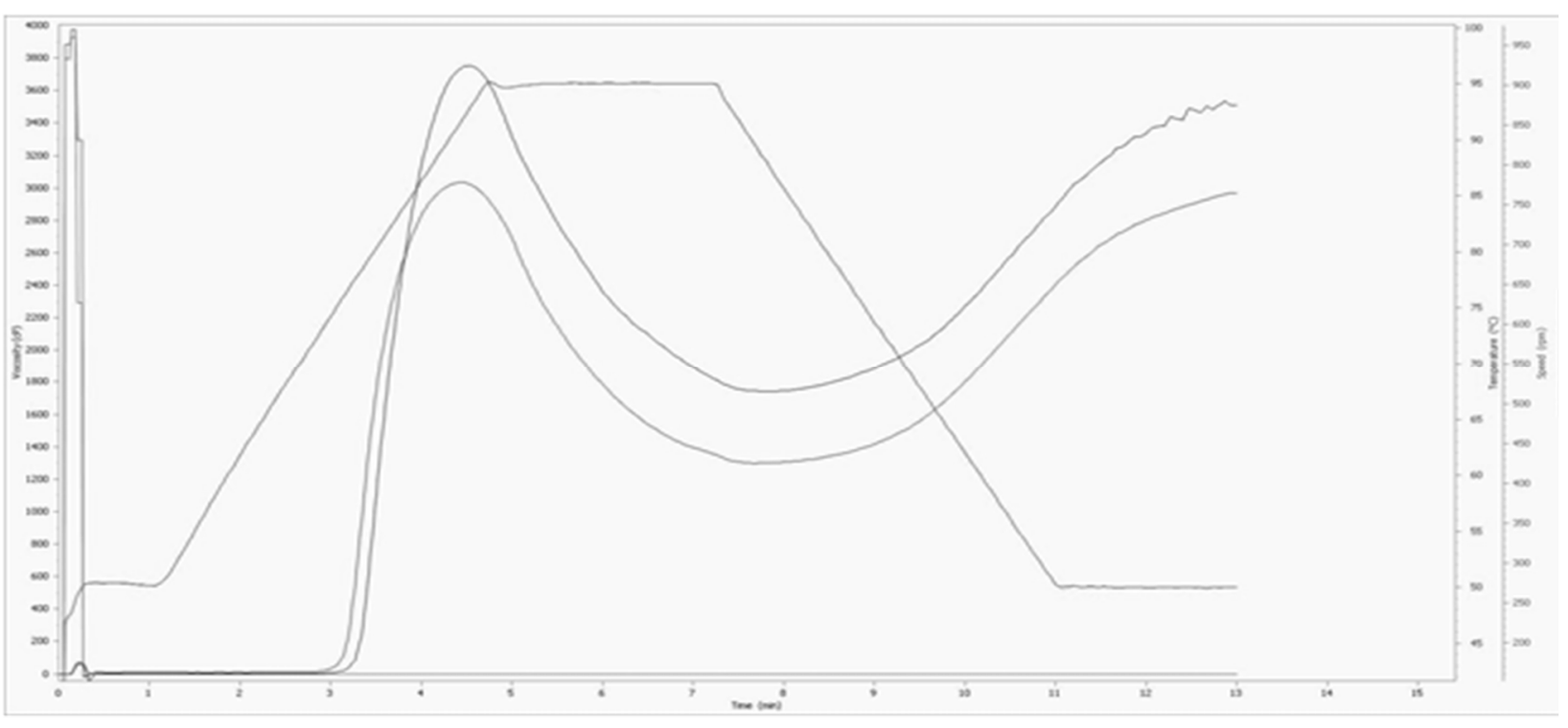

Figure 2. Viscograms of native and acetylated corn starch

Greatest difference between peak and viscosity after disintegration of wheat starch A granules probably due to the large size of the granules.

Accelerated peak viscosity (4.53) is noted for corn starch, which indicates that corn starch is easier to gelatinize. Relatively, low gelatinization temperature of corn starch at $76.7^{\circ} \mathrm{C}$ in native starch is probably due to the small size of granules. 


\section{Conclusions}

Comparative studies of the physicochemical properties of polysaccharides and their modifications have shown that acetylation leads to a decrease in the proportion of amylose in starch, and also reduces swelling.

It was found that with a decrease in the amount of the acetylating agent, a more uniform course of the reaction is observed, the granules destroyed after absorbing the maximum amount of moisture still have access points for replacement with acetyl groups, the reaction proceeds more slowly but deeper. Solubility depends more on the reaction time.

During the research, the optimal technological parameters for obtaining acetylated corn and wheat A starches were determined. The optimal acetylation parameters for wheat A starch are: the concentration of glacial acetic acid is 1:6, the reaction time is 40 minutes; for corn starch: concentration of glacial acetic acid 1:5, reaction time 60 minutes. The samples of acetylated starches obtained under these conditions are suitable for the formation of biodegradable materials from them in terms of their physicochemical properties.

\section{Acknowledgements}

The authors express their gratitude to the Science Committee of the Ministry of Education and Science of the Republic of Kazakhstan for funding this research within the framework of grant funding (Grant No. AP08857439).

\section{References}

1 Ojogbo E. Chemical and physical modifications of starch for renewable polymeric materials / E. Ojogbo, E.O. Ogunsona, T.H. Mekonnen // Materials Today Sustainability. — 2020. — Vol. 7, No. 8. — P. 150-161. https://doi.org/10.1016/j.mtsust. 2019.100028

2 Buleon P. Starch granules: structure and biosynthesis / P. Buleon, P. Colonna, V. Planchot, S. Ball // Int. J. Biol. Macromol. - 1998. - Vol. 5, No. 23. - P. 85-112.

3 Jenkins P.J. A universal feature in the structure of starch granules from different botanical sources / P.J. Jenkins, R.E. Cameron, A.M. Donald // Starch -Stärke. — 1993. - No. 45. - P. 417-420.

4 Miles M.J. The roles of amylose and amylopectin in the gelation and retrogradation of starch / M.J. Miles, V.J. Morris, P.D. Orford, S.G. Ring // Carbohydr. Res. - 1985. - No. 135. - P. 271-281.

5 Araújo M.A. Enzymatic degradation of starch-based thermoplastic compounds used in protheses: Identification of the degradation products in solution / M.A. Araújo, A. Cunha, M. Mota // Biomaterials. — 2004. — No. 25. — P. $2687-2693$. https://doi.org/10.1016/j.biomaterials.2003.09.093

6 Zhang J.F., Sun X.Z. Mechanical properties of PLA / starch composites compatibilized by maleic anhydride / J.F. Zhang, X.Z. Sun // Biomacromolecules. — 2004. — No. 5. — P. 1446-1451. https://doi.org/10.1021/bm0400022

7 Luo Z. Effect of Ultrasonic Treatment on the Physicochemical Properties of Maize Starches Differing in Amylose Content / Z. Luo, X. Fu, X. He, F. Luo, Q. Gao, S. Yu // Starch-Stärke. - 2008. - Vol. 11, No.60. - P.646-653. https://doi.org/10.1002/star.200800014

8 Singh J. Factors influencing the physico-chemical, morphological, thermal and rheological properties of some chemically modified starches for food applications - A review / J. Singh, L. Kaur, O.J. McCarthy // Food hydrocolloids. — 2007. — Vol. 21, No. 1. - P. 1-22. https://doi.org/10.1016/j.foodhyd.2006.02.006

9 Juliano B.O. A simplified assay for milled-rice amylose / B.O. Juliano // Cereal Science Today. — 1971. — Vol. 16 , No. 11. - P. 424-426.

10 Kumoro A.C. Preparation and characterization of physicochemical properties of glacial acetic acid modified Gadung (Diocorea hispida Dennst) flours / A.C. Kumoro, R. Amalia, C.S. Budiyati, D.S. Retnowati, R. Ratnawati // Journal of Food Science and Technology. — 2015. — Vol. 10, No. 52. - P. 6615-6622. https://doi.org/10.1007/s13197-015-1723-5

11 Wurzburg O.B. Converted starches. Modified starches: Properties and uses / O.B. Wurzburg. — Orlando: Orlando University Press, 1986. - 403 p.

12 Li J. Relationships between Thermal, Rheological Characteristics and Swelling Power for Various Starches / J. Li, A. Yeh // Journal of Food Engineering. — 2001. — No. 50. — P. 141-148. http://doi.org/10.1016/S0260-8774(00)00236-3

13 Cornejo-Ramírez Y.I. The structural characteristics of starches and their functional properties / Y.I. Cornejo-Ramírez, O. Martínez-Cruz, C.L. Del Toro-Sánchez, F.J. Wong-Corral, J. Borboa-Flores, F.J. Cinco-Moroyoqui // CyTA — Journal of Food. — 2018. - No. 16. - P. 1003-1017. http://doi.org/10.1080/19476337.2018.1518343

14 Raina C.S. Some characteristics of acetylated, cross-linked and dual modified Indian rice starches / C.S. Raina, S. Singh, A.S. Bawa, D.C. Saxena // Eur. Food. Res. Technol. — 2006. — No. 223. — P. 561-570. https://doi.org/10.1007/s00217-005-0239-z

15 Bartz J. Acetylation of barnyardgrass starch with acetic anhydride under iodine catalysis / J. Bartz, J.T. Goebel, M.A. Giovanaz, E. da Rosa Zavareze, M.A. Schirmer, A.R. Guerra Dias // Food Chemistry. — 2015. — Vol. 6, No. 23. - P. 178242. 
16 Šárka E. Application of wheat B-starch in biodegradable plastic materials / E. Šárka, Z. Kruliš, J. Kotek, L. Růžek, A. Korbářová, Z. Bubník, M. Růžková // Czech J. Food Sci. — 2011. — No. 29. — P. 232-242.

\author{
Е.Е. Ермеков, Д.Б. Тоймбаева, С.Г. Каманова, Л.А. Мурат, \\ М. Мұратхан, С.А. Садуахасова, Г.С. Айдарханова, Г.Х. Оспанкулова \\ Ацетилендірудің дәнді крахмалдардың физика-химиялық \\ қасиеттеріне әсерін зерттеу
}

\begin{abstract}
Композитті биологиялық ыдырайтын материалдарды өндіруде ацетилденген крахмалдарды қолдану перспективті бағыт болып табылады, өйткені ацетилдеу крахмалдардың суға төзімді қасиеттерін арттырады. Мақалада А бидайын және жүгері крахмалдарын мұзды сірке қышқылымен ацетилдеуде полисахаридтердің физика-химиялық қасиеттеріне әсері және биологиялық ыдырайтын пленкалардың композициялық қоспасын алу үшін модификацияланған крахмалдарды қолдану әлеуетін зерттеу бойынша нәтижелері келтірілген. Полисахаридтер мен олардың модификаттарының физика-химиялық қасиеттерін салыстырмалы зерттеу ацетилдеудің крахмалдағы амилозаның үлесінің төмендеуіне әкелетінін, сонымен қатар, крахмалдың ісінуін төмендететінін көрсетті. Крахмалдардағы алмастыру дәрежесі ацетилдеу реакциясының бастапқы кезеңдерінде ғана өсетіні анықталды, бұл ісіну және клейстеризация кезінде жүгері мен А бидайының крахмалдарының ортақ реологиясымен байланысты болуы мүмкін. Ацетилдеуші агент мөлшерінің азаюы кезінде реакцияның біркелкі ағымы байқалады, ең көп мөлшерде ылғалды өз бойына сіңіргеннен кейін ыдыраған түйіршіктер ацетил топтарын алмастыру нүктелеріне ие, реакция баяу, бірақ тереңірек жүреді. Ерігіштік реакцияның жүру уақытына байланысты. Ацетилденген крахмалдарды өндірудің оңтайлы технологиялық параметрлері анықталды. Сонымен, А бидайы крахмалы үшін: сірке мұз қышқылының концентрациясы 1:6, реакция уақыты 40 минут; жүгері крахмалы үшін: сірке мұз қышқылының концентрациясы 1:5, реакция ұзақтығы 60 минут. Осындай жағдайларда алынған ацетилденген крахмалдардың үлгілері биологиялық ыдырайтын материалдардың композициялық қоспасын алу үшін жақсы сәйкес келеді.
\end{abstract}

Кілт сөздер: А бидайы крахмалы, жүгері крахмалы, амилоза, ісіну, ерігіштік, ацетилендіру, реология.

\author{
Е.Е. Ермеков, Д.Б. Тоймбаева, С.Г. Каманова, Л.А. Мурат, \\ М. Муратхан, С.А. Садуахасова, Г.С. Айдарханова, Г.Х. Оспанкулова
}

\title{
Исследование влияния ацетилирования на физико-химические свойства зерновых крахмалов
}

\begin{abstract}
Использование ацетилированных крахмалов в получении композитных биоразлагаемых материалов является перспективным направлением, так как ацетилирование увеличивает водорезистентные свойства крахмалов. В статье представлены результаты исследований по влиянию ацетилирования ледяной уксусной кислотой пшеничного А и кукурузного крахмалов на физико-химические свойства полисахаридов и изучению потенциала использования модифицированных крахмалов для получения композиционной смеси биоразлагаемых пленок. Сравнительные исследования физико-химических свойств полисахаридов и их модификатов показали, что ацетилирование приводит к снижению доли амилозы в крахмале, а также набухаемости крахмала. Выявлено, что степень замещения в крахмалах растет только на начальных этапах реакции ацетилирования, что, возможно, связано с реологией крахмалов, общих для кукурузного и пшеничного А, во время набухания и клейстеризации. С уменьшением количества ацетилирующего агента наблюдается более равномерное течение реакции, гранулы, разрушенные после вбирания в себя максимального количества влаги, все еще имеют точки доступа для замещения ацетильными группами, реакция протекает медленнее, но глубже. Растворимость больше зависит от времени прохождения реакции. Определены оптимальные технологические параметры получения ацетилированных крахмалов. Так, для пшеничного А крахмала оптимальными являются: концентрация уксусной ледяной кислоты 1:6, время реакции 40 мин; для кукурузного крахмала: концентрация уксусной ледяной кислоты 1:5, длительность реакции 60 мин. Полученные при таких условиях образцы ацетилированных крахмалов хорошо подходят для получения композиционной смеси биоразлагаемых материалов.
\end{abstract}

Ключевые слова: пшеничный А крахмал, кукурузный крахмал, амилоза, набухаемость, растворимость, ацетилирование, реология. 


\section{References}

1 Ojogbo, E., Ogunsona, E., \& Mekonnen, T. (2020). Chemical and physical modifications of starch for renewable polymeric materials. Materials Today Sustainability, 7-8, 100028. https://doi.org/10.1016/j.mtsust.2019.100028

2 Buléon, A., Colonna, P., Planchot, V., \& Ball, S. (1998). Starch granules: structure and biosynthesis. International Journal of Biological Macromolecules, 23 (2), 85-112. https://doi.org/10.1016/s0141-8130(98)00040-3

3 Jenkins, P.J., Cameron, P.J., \& Donald, A.M. (1993). A universal feature in the structure of starch granules from different botanical sources. Starch-Stärke, 45, 417-420.

4 Miles, M.J., Morris, V.J., Orford, P.D., \& Ring, S.G. (1985). The roles of amylose and amylopectin in the gelation and retrogradation of starch. Carbohydrate Research, 135 (2), 271-281. https://doi.org/10.1016/s0008-6215(00)90778-x

5 Araújo, M.A., Cunha, A., \& Mota, M. (2004). Enzymatic degradation of starch-based thermoplastic compounds used in protheses: identification of the degradation products in solution. Biomaterials, 25 (13), 2687-2693. https://oi.org/10.1016/ j.biomaterials.2003.09.093

6 Zhang, J.F., \& Sun, X.Z. (2004). Mechanical Properties of Poly (lactic acid) / Starch Composites Compatibilized by Maleic Anhydride. Biomacromolecules, 5 (4), 1446-1451. https://doi.org/10.1021/bm0400022

7 Luo, Z., Fu, X., He, X., Luo, F., Gao, Q., \& Yu, S. (2008). Effect of Ultrasonic Treatment on the Physicochemical Properties of Maize Starches Differing in Amylose Content. Starch-Stärke, 11 (60), 646-653. https://doi.org/10.1002/star.200800014

8 Singh, J., Kaur, L., \& McCarthy, O. (2007). Factors influencing the physico-chemical, morphological, thermal and rheological properties of some chemically modified starches for food applications - A review. Food Hydrocolloids, 21 (1), 1-22. https://doi.org/10.1016/j.foodhyd.2006.02.006

9 Juliano, B.O. (1971). A simplified assay for milled-rice amylase. Cereal Science Today, 16 (11); 424-426.

10 Kumoro, A.C., Amalia, R., Budiyati, C.S., Retnowati, D.S., \& Ratnawati, R. (2015). Preparation and characterization of physicochemical properties of glacial acetic acid modified Gadung (Diocorea hispida Dennst) flours. Journal of Food Science and Technology, 52 (10), 6615-6622. https://doi.org/10.1007/s13197-015-1723-5

11 Wurzburg, B. (1987). Modified starches; properties and uses. Orlando: Orlando University Press.

12 Li, J., \& Yeh, A. (2001). Relationships between thermal, rheological characteristics and swelling power for various starches. Journal of Food Engineering, 50 (3), 141-148. https://doi.org/10.1016/s0260-8774(00)00236-3

13 Cornejo-Ramírez, Y.I., Martínez-Cruz, O., Del Toro-Sánchez, C.L., Wong-Corral, F.J., Borboa-Flores, J., \& CincoMoroyoqui, F.J. (2018). The structural characteristics of starches and their functional properties. CyTA - Journal of Food, 16:1, 1003-1017. http://doi.org/10.1080/19476337.2018.1518343

14 Raina, C.S., Singh, S., Bawa, A.S., \& Saxena, D.C. (2006). Some characteristics of acetylated, cross-linked and dual modified Indian rice starches. European Food Research and Technology, 223 (4), 561-570. https://doi.org/10.1007/s00217-005-0239-z

15 Bartz, J., Goebel, J. T., Giovanaz, M. A., da Rosa Zavareze, E., Schirmer, M. A., \& Guerra Dias, A.R. (2015). Acetylation of barnyardgrass starch with acetic anhydride under iodine catalysis. Food chemistry, 6 (23), 178-242.

16 Šárka E., Kruliš Z., Kotek J., Růžek L., Korbářová A., Bubník Z., \& Růžková M. (2011). Application of wheat B-starch in biodegradable plastic materials. Czech J. Food Sci., 29; 232-242 